\title{
Modelling of Soil Respiration in Hungary
}

\author{
F. ÁCS and H. BREUER \\ Eötvös Loránd University, Department of Meteorology, Budapest
}

Carbon dioxide is produced in soils primarily by soil organisms and by the respiration of roots. Most of the produced $\mathrm{CO}_{2}$ is released to the atmosphere; this process can be referred to as soil respiration, soil- $\mathrm{CO}_{2}$ emission or soil- $\mathrm{CO}_{2}$ efflux (hereafter the term soil respiration will be used). Soil respiration (SR) is a dominant term in the carbon budget of terrestrial ecosystems; it is comparable with NPP (net primary productivity). Despite its importance it is poorly quantified, as there are no operatively organized observations, much rather in situ measurements. Some of these are remarkably summarized by RAICH and SCHLESINGER (1992). On the basis of these measurement results soil respiration models were also constructed (e.g. RAICH \& SCHLESINGER, 1992; RAICH \& POTTER, 1995; RAICH et al., 2002), including not only process-based ecosystem models (RAICH et al., 1991) but also simple regression approaches driven by climate data (e.g. REICHSTEIN et al., 2003; PENG et al., 1998). Site specific in situ soil respiration measurements have been carried out in Hungary as well (NAGY \& BALOGH, 2005; TuBA et al., 2004; TÓTH \& Koós, 2005; GYURICZA, 2004). The first local-scale soil respiration estimations in Hungary were performed by ÁCS et al. (2005) and ÁCS and BREUER (2005). In these studies, a simple process-oriented Thornthwaite-based (THORNTHWAITE, 1948) bucket model is used; the soil respiration/evapotranspiration/climate relationship is analyzed.

The study presents the climatology of soil respiration in Hungary. The results obtained by the Thornthwaite-based biogeochemical model (BREUER, 2004) using climate and soil data were also analyzed statistically to gain simple linear leastsquare approaches for establishing the relationship between soil respiration and climate. These regression type soil respiration models can be used as recipes for estimating the annual, growing season and monthly values of soil respiration.

\section{Method and Data}

Method. - The Thornthwaite-based biogeochemical model consists of Thornthwaite's bucket model (THORNTHWAITE, 1948) and Peng's soil respiration model (PENG et al., 1998). Description of the model can be found in BREUER (2004). 
Thornthwaite's water budget and climate classification model (THORNTHWAITE, 1948 ) is process oriented and as simple as possible. Its advanced feature is that it uses not only atmospheric state variables, but also soil hydrophysical properties as inputs. Peng's soil respiration model (PENG et al., 1998) is a simple statistical model that uses annual values of precipitation $(\mathrm{P})$, air temperature $(\mathrm{T})$ and actual evapotranspiration (AET) as inputs. Soil respiration is obtained by the stepwise regression analysis of data collected by RAICH and SCHLESINGER (1992).

Data. - Soil water budget calculations are performed for 125 climatic stations in Hungary. Monthly values of precipitation $(\mathrm{P})$ and air temperature $(\mathrm{T})$ are taken from the Climate Atlas of Hungary (KAKAS, 1960). These data refer to the period 1901-

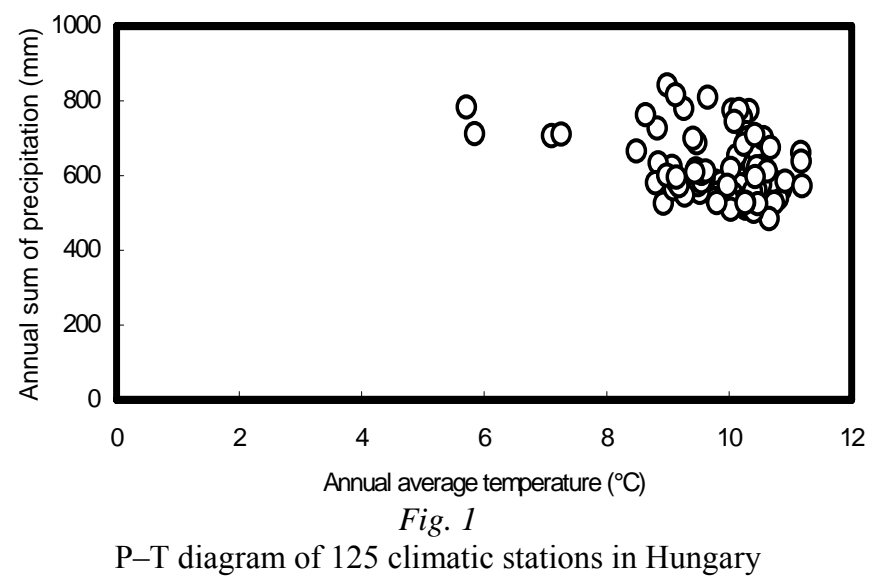

1950. It has to be noted that $\mathrm{P}$ and $\mathrm{T}$ climatic fields obtained by KAKAS (1960) agree well with the newest $\mathrm{P}$ and $\mathrm{T}$ climatic fields presented in the Climate Atlas of Hungary (2000). These data are presented as P-T diagram in Fig. 1.

Soil texture is determined by using the 1:100.000 scale soil texture map of the GIS Laboratory of the Research Institute for Soil Science and Agricultural Chemistry of the Hungarian Academy of Sciences (VÁRALLYAY et al., 1980). According to the map there are five main textural classes (as well as rocky and organic soils). Soil water holding capacity is calculated after NEMES (2003), and FODOR and RAJKAI (2005). In NEMES's (2003) study the fitting parameters of VAN GENUCHTEN's (1980) pF-curves are given for Hungarian soils using the 11 soil texture categories of the USDA soil classification. The correspondence between the Hungarian and the USDA texture classifications is determined by FILEP and FERENCZ (1999; see Eq. (8)). The wilting point is calculated for $\mathrm{pF}=4.2$, while the field capacity for $\mathrm{pF}=2.5$. The water holding capacity of rocky (4 stations) and organic (3 stations) soils are considered to be $100 \mathrm{~mm}$ (as given in THORNTHWAITE, 1948), because textural effects are fairly site specific on these soils. The wilting point, field capacity and water holding capacity for the five main soil texture classes are presented in Table 1. 
Table 1

Wilting point, field capacity and water holding capacity (in $\mathrm{mm}$ water $/ 100 \mathrm{~cm}$ deep root zone) of the five main texture groups as determined by NEMES (2003) and FODOR and RAJKAI (2005)

\begin{tabular}{|l|c|c|c|}
\hline \multirow{2}{*}{$\begin{array}{c}\text { Main textural } \\
\text { classes }\end{array}$} & Wilting point & Field capacity & Water holding capacity \\
\cline { 2 - 4 } & \multicolumn{3}{|c|}{$\mathrm{mm}$ water/100 cm deep root zone } \\
\hline Sand & 15.2 & 79.9 & 64.7 \\
Sandy loam & 104.7 & 273.8 & 169.1 \\
Loam & 135.5 & 331.7 & 196.3 \\
Clay loam & 175.0 & 386.9 & 211.9 \\
Clay & 271.9 & 485.4 & 213.4 \\
\hline
\end{tabular}

\section{Results and Discussion}

The validation of the model for Hungarian conditions is in process; therefore validation experiment results are missing from this study. Nevertheless, it has to be mentioned that Peng's model (PENG et al., 1998) is constructed on the basis of field measurements after the careful statistical evaluation of data. The results are discussed analyzing the areal distribution of SR and the statistical relationships between the SR and the climatic variables [P, T, AET, SW (soil water storage in $1 \mathrm{~m}$ deep root zone)] irrespectively whether the variable is input or output.

Areal distribution: The annual sum of soil respiration (SR) ranges between 380$470 \mathrm{~g} \mathrm{C}^{-2} \mathrm{~m}^{-2} \cdot$ year $^{-1}$ (Fig. 2). This is in agreement with data published by RAICH and SCHLESINGER (1992). The areal distribution of SR is similar to that of AET and the

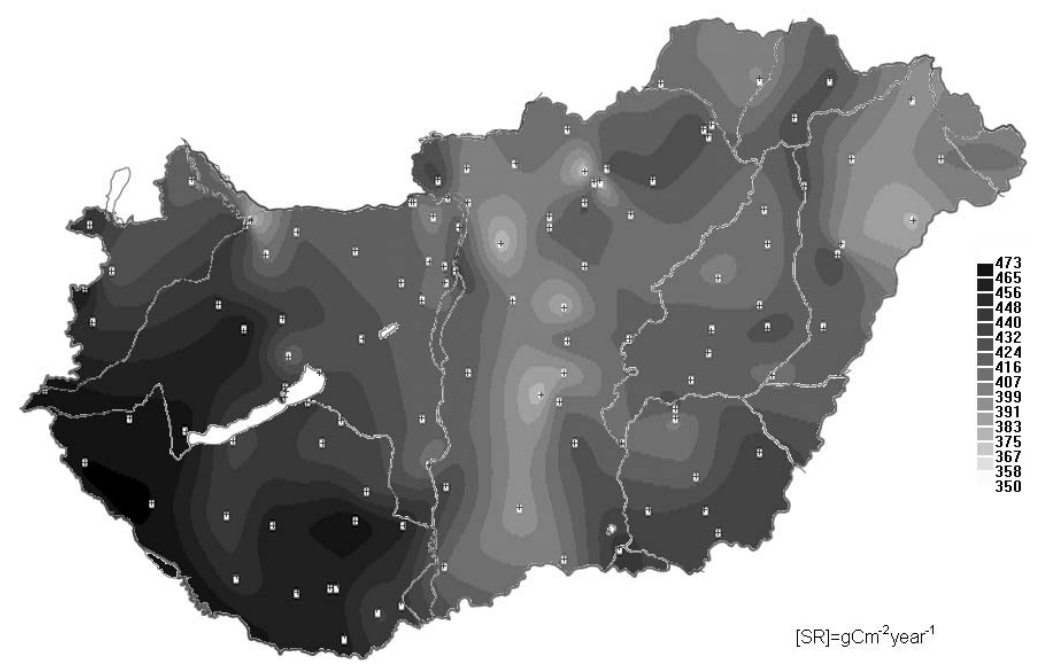

Fig. 2

Areal distribution of the annual sum of soil respiration (SR) 
climate formulae (ÁCS et al., 2005). SR value is the largest in B1 climates in mountain regions and on the hills where $\mathrm{C} 2$,s climate prevails. In these cases SR is determined by AET to a great extent, whereas AET is by the relief. SR is dependent of AET not only via relief, but also via soil texture. This becomes evident when the areal distribution of SR and soil texture are compared (not presented here). The areal distribution of SR is strongly influenced by sandy soils. The smallest SR val-

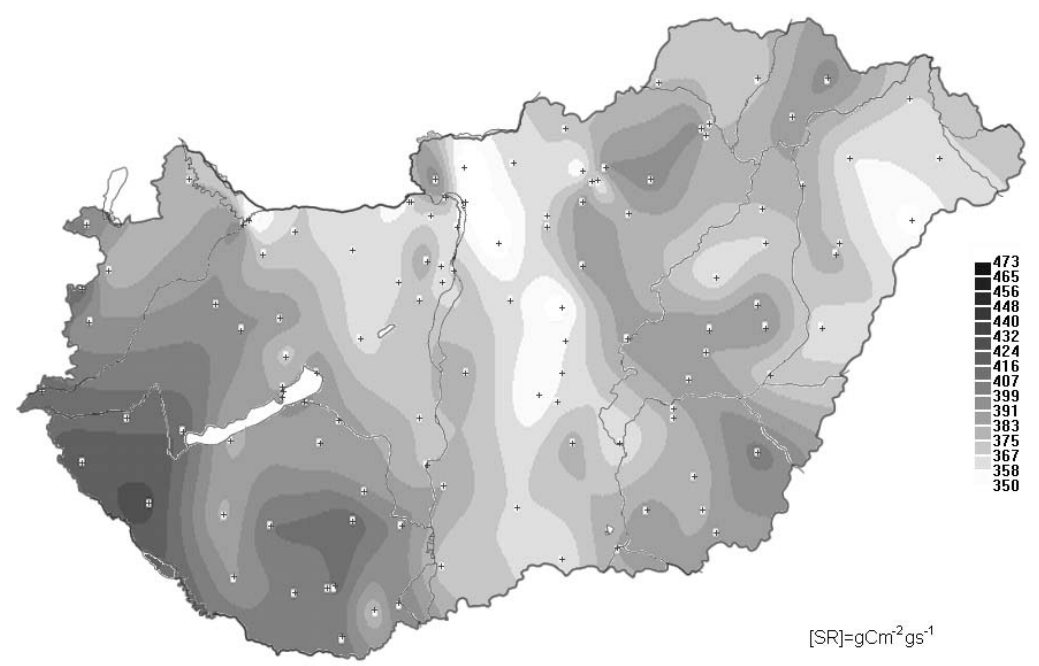

Fig. 3

Areal distribution of the sum of soil respiration (SR) in the growing season (from March to end of November)

ues are found in sandy regions of the Kiskunság and Nyírség, in many cases amounting to only about $380-400 \mathrm{~g} \mathrm{C} \cdot \mathrm{m}^{-2} \cdot \mathrm{year}^{-1}$. This effect of sand can also be seen in the climate formulae (DRUCZA \& ÁCS, 2006).

The growing season (starting in March and ending in November) sum of SR is between 350 and $420 \mathrm{~g} \mathrm{C} \cdot \mathrm{m}^{-2} \cdot \mathrm{gs}^{-1}$ (Fig. 3). Note that this distribution is very similar to the former one. The effect of areal distribution of sand is observable unequivocally.

Although the areal distribution of SR in May (Fig. 4) has a minimum value (35$\left.40 \mathrm{~g} \mathrm{C} \cdot \mathrm{m}^{-2} \cdot \mathrm{month}^{-1}\right)$ in sandy areas of the Kiskunság and Nyírség, the areal distribution differs from the former two cases. Maximum values $\left(50-55 \mathrm{~g} \mathrm{C} \cdot \mathrm{m}^{-2} \cdot \mathrm{month}^{-1}\right)$ occur not only in mountain regions (Bakony, Mecsek) but also in the plains (e.g. Fejér and Bács county).

The areal distribution of SR in October - presented in Fig. 5 - ranges between 25-45 g C $\cdot \mathrm{m}^{-2} \cdot \mathrm{month}^{-1}$. The minimum values occur in sandy regions of the Kiskunság and of the Gödöllö Hills, while maxima are found in the South-western parts of the country. This areal distribution has some similarities to the previous ones, referring to annual and growing season periods. 


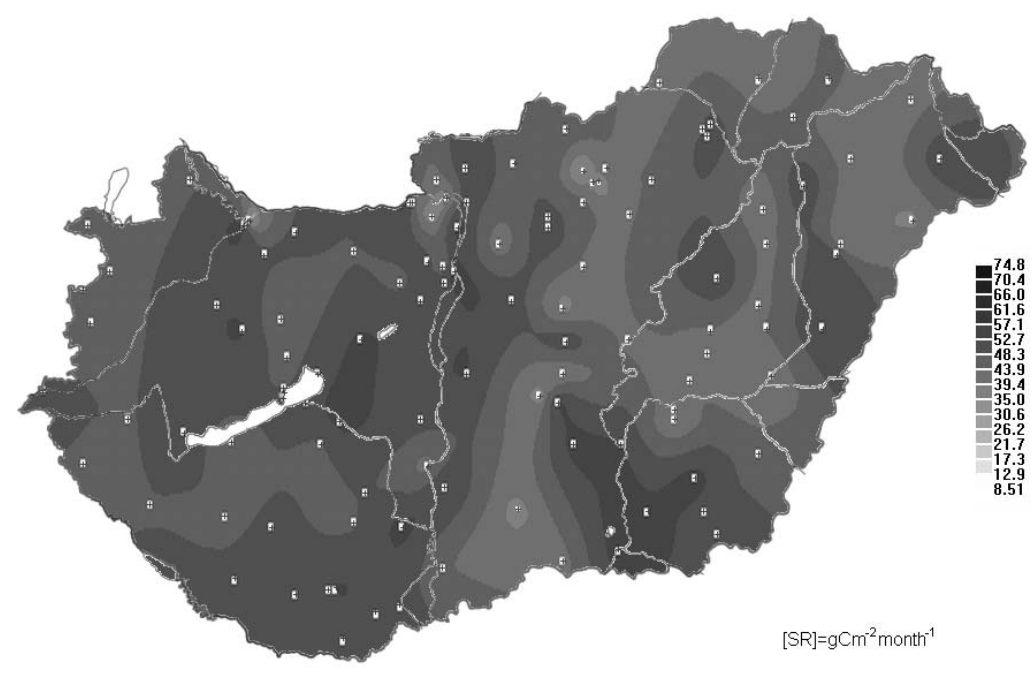

Fig. 4

Areal distribution of the sum of soil respiration (SR) in May

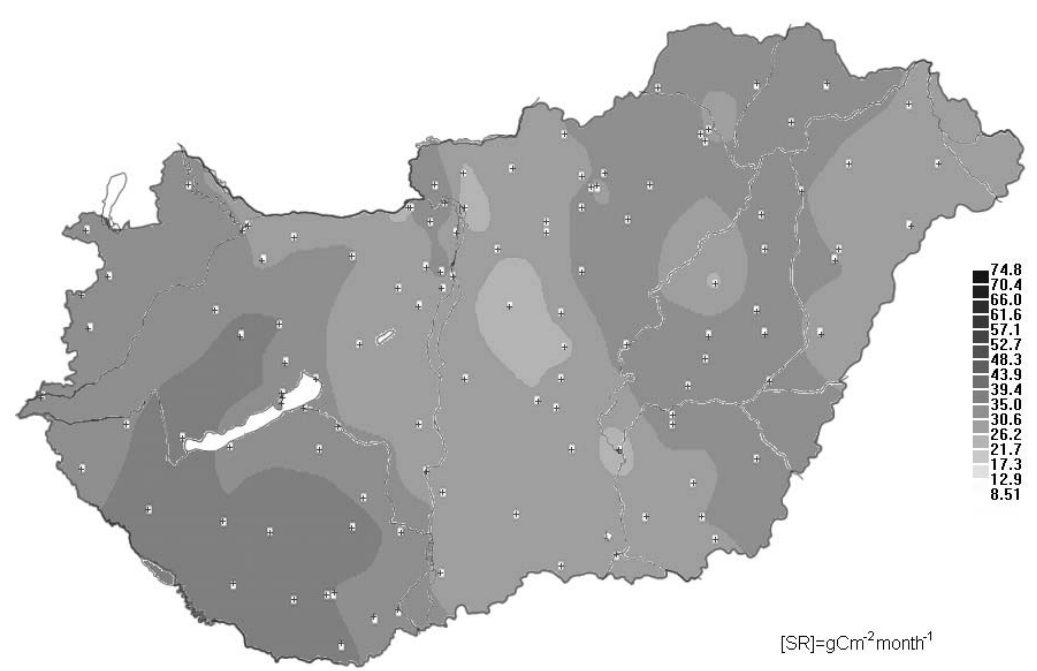

Fig. 5

Areal distribution of the sum of soil respiration (SR) in October

\section{Statistical relationships}

Relationships between SR and basic climatic variables (P, T, AET, SW); both inputs and outputs) are also analyzed statistically for annual, growing season and monthly time periods according to each soil texture group (sand, sandy loam, loam, clay loam and clay). Results (regression line $y=a \cdot x+b$ with the highest value of $\mathrm{R}^{2}$ ) 


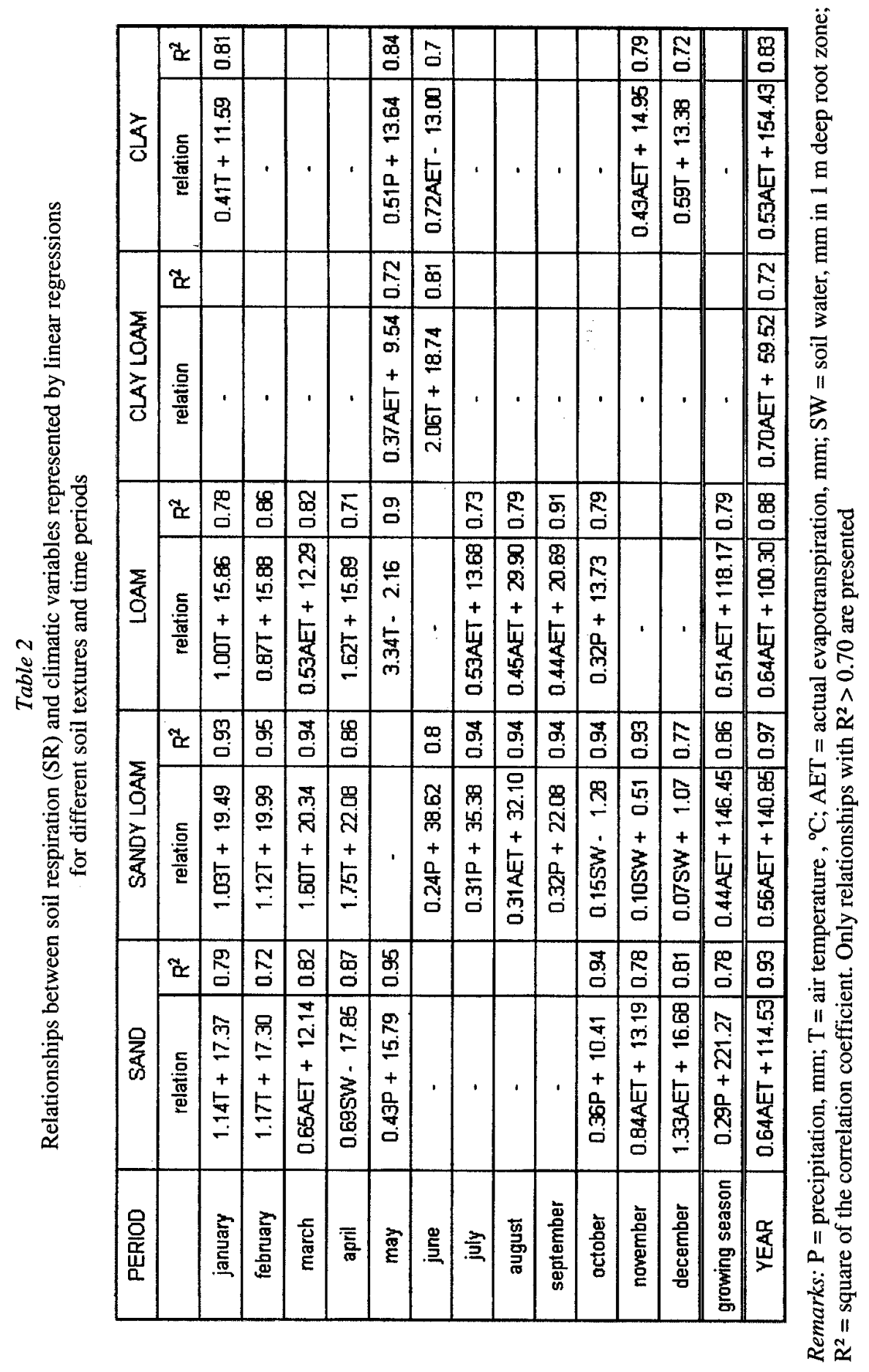


A
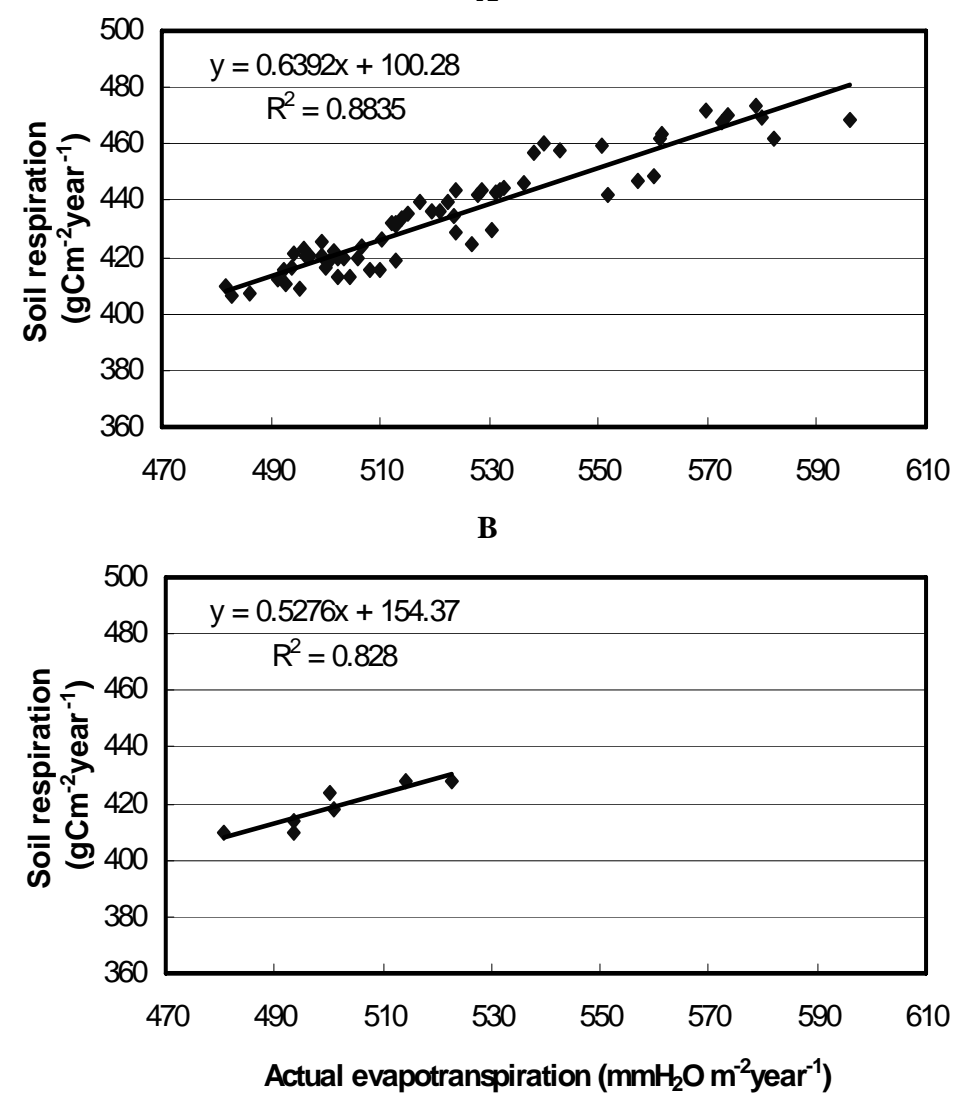

Fig. 6

Linear regression between annual values of SR and AET for loam (A) (relationship refers to 63 points) and clay (B) (relationship refers to 7 points) soil texture

are presented in Table 2. Results obtained for sand, sandy loam, loam, clay loam and clay refer to $16,9,63,21$ and 7 data points, respectively. In the following the results will be separately discussed with respect to different time periods and soil textures.

Annual period: $\mathrm{SR}^{\mathrm{an}}$ correlated well with $\mathrm{AET}^{\mathrm{an}}$ irrespective of soil texture (Fig. 6 ). The best correlation (0.97) is obtained for sandy loam; the worst $(0.72)$ for clay loam. Note that there is an obvious difference between their $b$ values. For sandy loam $b=140.85$, while for clay loam $b=59.5 \mathrm{~g} \mathrm{C} \cdot \mathrm{m}^{-2} \cdot \mathrm{year}^{-1}$. As it is shown by ÁcS et al. (2005) the areal pattern of $\mathrm{SR}^{\mathrm{an}}$ is strongly related not only to the areal pattern of $\mathrm{AET}^{\text {an }}$, but also to that of the mesoclimate (PÉCZELY, 1979).

Growing season: $\mathrm{SR}^{\mathrm{gs}}$ is also well correlated with $\mathrm{P}^{\mathrm{gs}}$ and with $\mathrm{AET}^{\mathrm{gs}}$. For sand, $\mathrm{P}$ is predictor, for clay loam there is no relation with $\mathrm{R}^{2}>0.70$, while in other cases 
the predictor is $\mathrm{AET}^{\mathrm{gs}}$. It can also be seen that $b$ is the largest, moderate and the smallest (with values 221.2, 146.49 and 118.2) for sand, loam and clay loam, respectively.

Monthly periods: In winter months SR is related to AET, SW and T. Among them the main predictor is $\mathrm{T}$ (see January and February for sand, sandy loam, loam and clay). In December SR can be well related not only to T but also to AET (see sand) and SW (see sandy loam). In spring and autumn the strength of the SR/climatic variables relations is much weaker than in the former case. There is no main predictor among the variables; all variables are represented. So, in March and April the predictor for sandy clay is T, but for sand it is AET and SW. In October and November the predictor for sand is P and AET, while for sandy loam it is SW. Note that for clay loam no strong relationships $\left(\mathrm{R}^{2}<0.70\right)$ were found at all. In summer months, in many cases no strong relationships could be established (e.g. for sand there weren't any, for clay loam and clay only in June). The predictor was usually AET or P in these cases.

Soil texture: It is obvious that more relationships were found between SR and climatic variables in case of coarser (sand, sandy loam and loam) than finer (clay loam and clay) soil textures. For clay loam, relationships are missing not only in the summer, but also in winter months. Note that in case of clay loam SR in June does not depend upon AET or P, but rather upon T, but only in this month.

\section{Conclusions}

Soil respiration fields in Hungary obtained by a Thornthwaite-based biogeochemical model (BREUER, 2004) using soil hydrophysical data after NEMES (2003) and FODOR and RAJKAI (2005), and climatic fields of precipitation and air temperature after KAKAS (1960) are studied. The validation of the model used is in process. SR fields are analyzed not only for different time periods (year, growing season and months) but also for different soil textures (sand, sandy loam, loam, clay loam and clay).

The main results are as follows: For annual and growing season periods there is a strong relationship between SR and AET. For monthly periods, the relationships are quite variable. SR is well correlated with $\mathrm{T}$ in winter months. In the summer period there is a simple linear relationship between SR and water balance components (P, AET, SW), but this is quite uncertain in some months.

Among climatic variables $\mathrm{P}$ and $\mathrm{T}$ are the most important, as they are operatively measured. AET and SW also seem to be important, but they are neither operatively measured nor operatively estimated. This is their great disadvantage. Taking all soil textures and months into consideration, totally 60 cases can be distinguished in Hungary. From these 60 cases, SR is correlated with P and T in 20 cases, with AET and SW in 15 cases. In 25 cases the relation was not strong enough $\left(\mathrm{R}^{2}<0.70\right)$. From these 25 cases 10 refer to clay loam, while 7 to clay (see Table 2). According to these brief statistics, to get SR, an operative estimate of AET and SW has to be achieved and further calculations have to be made for clay loam and clay. 


\section{Summary}

The climatology of soil respiration in Hungary is presented. Soil respiration is estimated by a Thornthwaite-based biogeochemical model using soil hydrophysical data and climatological fields of precipitation and air temperature. Soil respiration fields are analyzed for different soil textures (sand, sandy loam, loam, clay loam and clay) and time periods (year, growing season and months).

Strong linear relationships were found between soil respiration and the actual evapotranspiration for annual and growing season time periods. In winter months soil respiration is well correlated with air temperature, while in summer months there is a quite variable relationship with water balance components. The strength of linear relationship between soil respiration and climatic variables is much better for coarser than for finer soil texture.

The study is supported by the Hungarian Scientific Research Fund (Project No. T043695).

Key words: Hungary, soil respiration, air temperature, water balance components, linear relationship

\section{References}

ÁCS, F. \& BREUER, H., 2005. Relationship between the climate, evapotranspiration, and soil respiration in Hungary. Poster. $5^{\text {th }}$ Annual Meeting of the European Meteorological Society (EMS), $7^{\text {th }}$ European Conference on Applications of Meteorology (ECAM), 12-16 September 2005, Utrecht, The Netherlands.

ÁCS, F. et al., 2005. Modelling the relationship between soil and climate. (In Hungarian) Agrokémia és Talajtan. 55. 257-274.

BREUER, H., 2004. Soil/climate relationship from the point of view of Thornthwaite. (In Hungarian). Internal Report of ELTE Department of Meteorology. Budapest.

Climate Atlas of Hungary, 2000. Hungarian Meteorological Service. Budapest.

DRUCZA, M. \& ÁCS, F., 2006. Relationship between soil texture and near surface climate in Hungary. Időjárás. (In press)

FILEP, GY. \& FERENCZ, G., 1999. Recommendation for improving the accuracy of soil classifcation on the basis of particle composition. (In Hungarian) Agrokémia és Talajtan. 48. 305-320.

FODOR, N. \& RAJKAI, K., 2005. Computer program (TALAJTANonc 1.0) for the calculation of the physical and hydrophysical properties of soil from other soil characteristics. (In Hungarian) Agrokémia és Talajtan. 54. 25-40.

GYURICZA, Cs., 2004. Relationships between land use and greenhouse effects based on measured data. In: Land Use, Cultivation Effects, Soil Water. (Eds.: BIRKÁs, M. \& GYURICZA, Cs.) (In Hungarian) 47-60. Szent István University. Gödöllö.

KAKAS, J. 1960. Potential annual evapotranspiration. Annual water surplus. Annual water lack. In: Climatic Atlas of Hungary. 46/2-4. maps. Akadémiai Kiadó. Budapest. 
NAGY, Z. \& BALOGH, J., 2005. Personal communication.

NEMES, A., 2003. Multi-scale hydraulic pedotransfer functions for Hungarian soils. PhD. Dissertation. Wageningen University. The Netherlands.

Peng, C. H., Guiot, J. \& VAn CAMPO, E., 1998. Past and future carbon balance of European ecosystems from pollen data and climatic models simulations. Global Planet Change. 18. 189-200.

PÉCZEly, G., 1979. Climatology. (In Hungarian) Tankönyvkiadó. Budapest.

RAICH, J. W. \& PotTER, C. S., 1995. Global patterns of carbon dioxide emissions from soils. Global Biogeochemical Cycles. 9. 23-36.

RAich, J. W., POTTER, C. S. \& BHAGAWATI, D., 2002. Interannual variability in global soil respiration, 1980-94. Global Change Biol. 8. 800-812.

RAich, J. W. \& Schlesinger, W. H., 1992. The global carbon dioxide flux in soil respiration and its relationship to vegetation and climate. Tellus. 44B. 81-99.

RAICH, J. W. et al., 1991. Potential net primary productivity in South America: Application of a global model. Ecological Applications. 1. 399-429.

ReICHSTEIN, M. et al., 2003. Modeling temporal and large-scale spatial variability of soil respiration from soil water availability, temperature and vegetation productivity indices. Global Biogeochemical Cycles. 17. (4) 1104.

THORNTHWAITE, C. W., 1948. An approach toward a rational classification of climate. Geographical Rev. 38. 5-94.

TóTH, E. \& Koós, S., 2005. Carbon-dioxide emission measurements in long term experiments. In: Monitoring Space-Time Dynamics of Soil Chemical Properties to Improve Soil Management and Environmental Quality. Proc. Bilateral Cooperation Workshop between Flanders and Hungary, 8-9 Dec. 2005. (Eds.: CocKX, L. et al.) 83-94. Ghent.

TUBA, Z. et al., 2004. Functional ecological responses, C-cycle and greenhouse gas balances of Hungarian grasslands beside present and future climatic conditions and land utilizations. (In Hungarian) AGRO-21 Füzetek. 37. 123-138.

VAN GENUCHTEN, M. T., 1980. A closed-form equation for predicting the hydraulic conductivity of unsaturated soils. Soil Sci. Soc. Am. J. 44. 892-898.

VÁRALLYAY, GY. et al., 1980. Map of soil factors determining the agro-ecological potential of Hungary (1:100 000) II. (In Hungarian) Agrokémia és Talajtan. 29. 77112 . 